\title{
Pre-service Teachers' Thinking about Student Assessment Issues
}

\author{
Marielle Simon (Corresponding author) \\ Faculty of Education, University of Ottawa \\ 145 Jean-Jacques Lussier, Ottawa, Canada
}

Tel: 1-613-5625-800_E-mail: msimon@uottawa.ca

Stephanie Chitpin

Faculty of Education, University of Ottawa

145 Jean-Jacques Lussier, Ottawa, Canada

Tel: 1-613-0562-5800Ｅ-mail: schitpin@uottawa.ca

Raudhah Yahya

Faculty of Education, University of Ottawa

145 Jean-Jacques Lussier, Ottawa, Canada

\begin{abstract}
Pre-service teachers are typically concerned with student assessment and view related issues through varied experiences and backgrounds. Understanding how they think about assessment issues within the current educational context helps to better prepare them. In this paper we describe pre-service teachers' thinking about assessment issues, the theories that underlie their thinking, and how it evolves as a result of using an introspective critical approach called the objective knowledge growth framework. The framework combines the diary and the think aloud protocol and brings pre-service teachers to identify initial assessment problems, propose tentative solutions, and challenge their solutions. Thirty-one pre-service teachers took part in this study and received a one hour workshop on the use of the introspective approach to solve their self-identified assessment issues. Brookhart's 'Tensions in Classroom Assessment Theory and Practice' framework was then used to explore the theories at play when pre-service teachers go through their problem solving processes. The participants identified group work, test failure, accommodation, fairness, multiple assessment opportunities, and academic enablers as key areas of concern. Particularly notable in the study, was the greater importance attached by the pre-service teachers to assessment for classroom management, student motivation, and social justice purposes, than to support learning. The analysis of these concerns using Brookhart's framework and of the reasoning about them suggests that the intersection of measurement, psychological, and social theories continues to impact the decision making process regarding assessment.
\end{abstract}

Keywords: Assessment, Pre-service Education, Student evaluation 


\section{Introduction}

Assessment is one of the many concerns pre-service teachers have when entering teacher development programs. They come into the programs with varying degrees of knowledge, background, understanding, and experience with assessment. Their expectations regarding their anticipated professional development in assessment also differ greatly. Existing literature on teachers' views of assessment issues has produced results that have significantly informed the knowledge base and teaching development programs (i.e. Black \& Wiliam, 2006; Brookhart, 1993; 1994; 1999; Guskey, 2009; Harris, Irving, \& Peterson, 2008; McMillan, 2000; 2001; 2003; Saxe, Gearhart, Franke, Howard, \& Crockett, 1999; Stiggins, 1990, 2004; Stiggins, Friesbie \& Griswold, 1989). However additional investigations of pre-service teachers' pre-conceptions and level of awareness regarding the topic would further validate and substantiate this knowledge. This study was conducted to capture pre-service teachers' cognitive thinking about current assessment issues, their critical exploration of viable solutions, and the potential growth in their reasoning about solving practical assessment problems. More specifically, we sought to answer the following two questions: a) What are pre-service teachers' concerns about assessment when entering the Bachelor of Education program? and b) What theories underlie the solutions they offer to solve their identified concerns?

\section{Literature Review}

Increasing research on perceptions regarding assessment practices in the classroom with the advent of standards-based education reform has been typically focused on practicing teachers and has used traditional research means. For example, Black and Wiliam (2006) established specific conditions needed to successfully apply formative assessment. While also investigating formative assessment practices in science education, Cowie and Bell (1999) offered a dual cycle of planned and spontaneous interaction model of assessment. McMillan (2007) further developed the concept of fairness in classroom assessment whereas Torrance and Pryor (2001) studied the social nature of assessment and power relationships. Studies by Harris and Brown (2008) on teachers' concepts of student and teacher accountability and by Sauve Johnson (2001), on teachers' awareness of assessing targeted standards and criteria were among the few to use introspective approaches to specifically investigate practicing teachers' thinking about assessment. Such research led to the production of partial assessment theories and frameworks that have been used to structure course on assessment in teacher development programs.

A few studies have reported results of surveys of pre-service teachers' literacy level regarding assessment. Childs and Lawson (2003) for example found that teacher candidates generally held negative opinions regarding large-scale assessments. Volante and Fazio (2007) observed that teacher candidates offered summative assessment as the main purpose of assessment and preferred observation techniques of assessment. Finally, Graham (2005) used interviews to look at how the assessment theories of pre-service teachers changed in a mentored environment. Overall, her study uncovered five categories of concerns pre-service teachers have regarding classroom assessment: a) designing learning goals, b) rubrics, grading and fairness, c) grading and motivation, d) assessment validity and c) the time required to assess 
this way (p. 607). Our anecdotal study builds incrementally on the current research by further tapping into pre-service teachers' introspective critical analysis of self-identified assessment issues and of their proposed solutions to solve them. The approach is novel in that it allows participants to actively interact with their thoughts and reasoning and to challenge their solutions as they go through the problem solving process.

\section{Conceptual Framework}

In the early1990s, key influential scholarly works by Black and Wiliam, (1998) Gipps, (1994) and Shephard (2000) highlighted the need to develop a unified theoretical basis for assessment in education. A decade later, Brookhart (2004b) reviewed empirical studies on assessment with a focus on their theoretical frameworks. She found that the frameworks varied widely and that the practice of educational assessment occurred at the intersection of three practical bases: instruction, classroom management, and classroom assessment, and at the interaction of three theoretical bases: psychology, sociology, and measurement (p. 430). She further proposed that the current lack of a comprehensive theory of educational assessment may explain the tension teachers feel when assessing student learning.

Figure 1 depicts an adapted version of Brookhart's (2004b) visual flowchart for studying pre-service teachers' introspective thinking about assessment issues. The middle box shows the original version where the three theoretical bases surround the three practical bases of educational assessment. The elements outside that box have been added to show the introspective reasoning process based on Popper's critical rationalism associated with his falsification theory (see also section 4.2). It starts with the identification of the assessment problem followed by the selection of an assessment principle that may help solve that problem. The third step involves actively challenging and critiquing chosen principle which can result in three possible outcomes: a) assessment issue remains unsolved, b) issue is solved, or c) a new or reformulated issue emerges. The articulation of the outcome happens in step four. Within the circular introspective thinking context, all three outcomes are expected to eventually lead pre-service to consciously identify, adopt, and refine the various theories at play when addressing their assessment issues. Whereas Brookhart used the framework to conduct her literature review of 40 entries dated between 1982 and 2002, we used it to investigate the theoretical basis of a group of pre-service teachers' reasoning about practical classroom assessment problems.

Our study focuses particularly on the role of the intersection of the three theoretical bases but references to the three practical bases are also considered. Brookhart's (2004b) systematic review of the classroom assessment literature indicated that it most commonly referred to theory associated with educational psychology. She found that active involvement in learning and assessment led to enhanced student learning and that assessment feedback and its various characteristics played a major role in student motivation. From a sociological perspective, Brookhart highlighted two common theoretical frameworks that acknowledged the group nature of classroom assessments: classroom environment theory and socio-cultural learning theory. Each classroom develops a particular assessment environment with specific rules that stems from the teacher's general approach to teaching, learning, and assessment. Social constructivist learning theory situates learning in the interactions among people and assessments activities are considered as cultural events (Brookhart). Measurement theory 
focuses on quality and function. Quality includes principles of validity and reliability whereas function typically features the diagnostic, formative and summative roles of assessment.

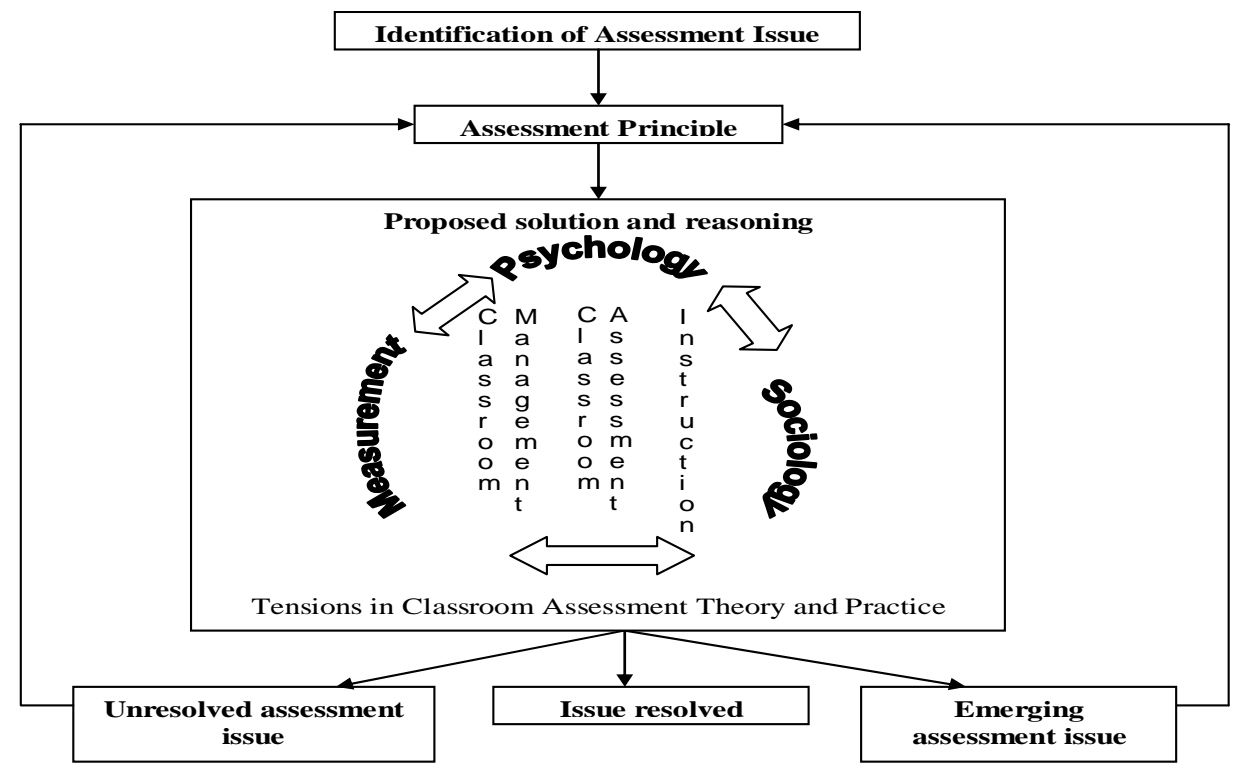

Figure 1. Adapted Brookhart's 2004b Tensions in Classroom Assessment Theory and Practice Framework.

The intersection of theories underlying the thinking and practice of classroom assessment is a result of their overlap in a way that often produces conflicts and tensions. This may explain why beginning and practicing teachers generally view classroom assessment as problematic. Examples of common assessment issues that are found at the intersection of theories are the roles of effort and achievement in grading and how to effectively complement formative and summative assessments within a context based on accountability and teacher professional judgment. Brookhart recommends that in order to evaluate the meaning, value, accuracy, and consistency of classroom assessment information, the intersection nature of theory underlying the classroom context should be acknowledged.

\section{Methodology}

An interpretive design was used for this study in order to provide a relatively narrow but high definition picture of a) how pre-service teachers view and critically think about classroom assessment issues and their potential solutions and b) how they gradually build their theoretical knowledge base in that field (Creswell, 2009; Newman, 2004; Wellington, \& Szczerbinski, 2007). The focused investigation of a segment of pre-service teachers' views of the complex world of classroom assessment contributes to the articulation of a series of assumptions and representations they may hold. This may provide the basis for the development of a useful platform or agenda for further empirical and scientific exploration.

\subsection{Participants}

The initial project from which this study evolved included pre-service teachers from three sections of a thirty-nine hour course titled 'Curriculum Design and Evaluation' offered in fall 
of 2008 at the Intermediate and Senior levels. This course was part of an eight-month Bachelor of Education program in a university from Ontario, Canada. In this sub-study, only the results of one section were examined for the following three reasons. First, a smaller sample was adopted in order to delve deeply into pre-service teachers' thoughts and reasoning about assessment issues and to report these in detail. Second, this group was the third to receive a one-hour workshop on the approach which means that the workshop was field tested on the first two groups and subsequently revised as a result. Third, the group was the most heterogeneous group of the three. It included many mature students, with some having up to ten years of work experience. Of the 37 pre-service teachers enrolled in the course, 31 consented to participate in the study.

\subsection{Data Source}

Data on the pre-service teachers were obtained using an innovative introspective approach based on Popper's critical rationalism (1972) and referred to in this study as the Objective Knowledge Growth Framework (OKGF). For a detailed description of Popper's epistemology, readers are encouraged to read Chitpin (2006). The approach combines reflective data collection techniques such as diaries and think aloud protocols, and involves a four step cyclical schema described as: P1-TT-EE-P2, where P1 is the identification of an initial problem (e.g. an assessment issue); TT refers to the proposal of a tentative theory or solution to the problem; EE means the critical process of error elimination which leads to P2, the next problem, and so on. Unsuccessful attempts to eliminate errors may turn out to be just as important for further development as successful ones (Popper, p.177). A specific OKGF template, containing space for the documentation of up to three cycles was used for collecting the introspective data. Each cycle of the OKGF corresponded to Popper's schema (see Appendix B for examples of completed templates).

\subsection{Procedure}

An hour workshop was given to the pre-service teachers on the use of the OKGF. The first author, who was not teaching the course, conducted the workshop prior to the pre-service teachers' field placement. Using a slide presentation and numerous examples, the purpose and each steps of the OKGF were explained. The workshop was given during the first module on assessment and thus the pre-service teachers received a list of assessment principles from the Ontario Ministry of Education (OME)'s Growing Success document (2008, p. 2-I) and Understanding by Design (UbD) (Wiggins \& McTighe, 2005, p. 24) to help them propose solutions to their identified assessment issues.

It should be noted that the principles are themselves grounded in the three theoretical bases. For example, the principle "teachers must use assessment and evaluation strategies that are varied in nature, administered over a period of time, and designed to provide students with opportunities to demonstrate the full range of their learning” (OME, 2008, p. 2-I) is clearly grounded in current measurement theory. The principle "assessment and evaluation strategies that are fair to all students" (OME) is rooted in social theory, and the principle "teachers must use assessment and evaluation strategies that accommodate the needs of students with special education needs, consistent with the strategies outlined in their Individual Education Plan” 
(OME) arises from psychological theories of individual differences.

During the workshop, the participants worked in groups of three to five, resulting in eight groups. They were given a blank OKGF template. The completed group cycles were submitted to the professor immediately after the workshop. At the end of the workshop, the participants were instructed to individually complete the next cycles of the OKGF template and to submit it after their field placement in mid-December. They were also informed that they could use the group cycle as the initial cycle to complete their template or address an initial assessment issue of their choice. Although the OKGF template has space for three cycles, the participants were told that they did not need to limit themselves to three cycles only. The group work was worth $10 \%$ of the students' grade in the course whereas the individual assignment was worth $20 \%$.

\subsection{Analysis}

Of the 31 templates received, three lacked coherence and fluidity and were therefore discarded. From the resulting 28 templates, we first drew a list of the initial and last assessment issues identified in order to get a sense of the pre-service teachers' changing views and diversity of assessment and related topics. Two individuals coded the list of assessment issues identified in the final cycles (A3). Their codes matched for 24 of the 28 issues, indicating an inter-rater reliability of $86 \%$. To obtain insight into the theory underlying the student's reasoning, one group of pre-service teachers $(n=4)$ was randomly selected from the groups who identified the two most popular assessment issues: failing a test and assessing group work. Content analysis was then applied to each of their completed OKGF templates (Newman, 2003; Wellington, \& Szczerbinski (2007). This analysis was done using a coding sheet based on Bookhart's (2004b) framework as adapted for the study.

\section{Findings and Discussion}

The presentation and discussion of findings is organized around the two research questions stated earlier in the paper: a) overall initial and final assessment issues identified, and d) insight into the theoretical bases of the pre-service teachers' reasoning about these issues.

\subsection{Initial and final assessment issues and principles}

Tables 1 and 2 respectively provide the list of initial and final assessment issues identified by the groups of pre-service teachers. Three observations are noted when comparing the two tables. First, four of the original issues reappear in the final cycles: group work, accommodating learning needs/styles, late assignments, and oral presentations. Second, the most popular initial assessment issues included students failing a test and assessment of group work. It is interesting to note that student failure is not a typical expression found in the assessment literature given the current discourse on success for all. Group work remained as popular in the final cycles and was again tied to the concern of providing multiple assessment opportunities. Although group and team work is strongly recommended in teaching and learning theories, it is less so in current measurement theory. Third, many of the issues identified in the initial cycle related to what is called 'academic enablers' such as effort and student participation (Duncan and Noonan, 2007; McMillan, 2003), or student predisposition, 
such as submitting late assignments (Marzano, 2000). These seem to have been replaced in the final cycles by a greater number of references to measurement principles such as reliability, validity and fairness. These observations suggest the potential of the OKGF to encourage pre-service teachers to freely identify genuine assessment concerns.

Table 1. Initial Assessment Issues

\begin{tabular}{|lc|}
\hline \multicolumn{1}{|c}{ Initial Assessment Issues } & $\begin{array}{c}\text { Participants } \\
\text { initial assessment issues }\end{array}$ \\
\hline Failing of tests/exams & (A3,A27,A7,A8,A28,A17) \\
\hline Group work & (B14,B26,B16,B25,B30,B13) \\
\hline Oral presentation & (C20,C19, C9) \\
\hline Late assignment & (D11,D6) \\
\hline $\begin{array}{l}\text { Accommodating learning } \\
\text { abilities/styles }\end{array}$ & (E2,E24,E1) \\
\hline Take home assignments & (F21,F15,F31) \\
\hline Absence from class & (G10, G29,G22) \\
\hline Assessment of participation & (H5) \\
\hline Creative writing & (I18) \\
\hline Total & 28 \\
\hline
\end{tabular}

Note: Assignments of participants coded 12, 4 and 23 were taken out.

Table 2. Final Assessment Issues Identified

\begin{tabular}{|lc|}
\hline \multicolumn{1}{|c|}{ Final Assessment Issues } & $\begin{array}{c}\text { Participants } \\
\text { final assessment issues }\end{array}$ \\
\hline Multiple Assessment Opportunities & (A7,A8,A28,B13,C9,E24,F21) \\
\hline Group work & (B14,B26,B16,B25,B30,C19,E1) \\
\hline Fairness in Assessment & (B25,D11,G10,G29,G22) \\
\hline $\begin{array}{l}\text { Accommodating learning } \\
\text { abilities/styles }\end{array}$ & (A27,B25,E2,H5) \\
\hline Validity of assessment & (A17,B26,E1) \\
\hline Oral presentation & (C20,C9) \\
\hline Student responsibility & (D6,F15) \\
\hline Late assignments & (F31,I18) \\
\hline Time management & (A3) \\
\hline Total & 35 \\
\hline
\end{tabular}

Note: Participants coded 12, 4 and 23 were taken out. Letters A, B, C, etc refer to groups of students who identified similar initial assessment issues.

The eventual formulation of emergent issues grounded in technical qualities across the OKGF cycles suggests greater awareness, by the pre-service teachers, of current assessment principles anchored in standards-based education. Such foundational changes in teachers' working assessment theories was found in Graham's 2005 study where pre-service teachers 
were initially 'clueless' about setting assessment goals (p. 612), equated the concept of assessment with testing, and assumed that student motivation was highly dependent on grades. At the end of their program, the pre-service teachers in Graham's study had a clearer concept of aligning assessment goals with teaching and curriculum expectations, and of the role of informal and continuous assessment. However, they still expressed concerns about how to develop effective rubrics, how to assess group work, how to accommodate learners with special needs, and questioned whether their assessments provided relevant and meaningful information regarding their students' achievement (p. 617). Interestingly, issues of group work, accommodation, and validity were concerns in both Graham's and our study.

\subsection{Theoretical insight into pre-service teachers' thinking about assessment issues}

This section describes the reasoning and its theoretical basis of four pre-service teachers who were part of the seven students that identified 'failing a test' as their initial cycle (see Appendix B for the transcripts of each completed OKGF template). Abby (A3), Bella (A7), Carrie (A27) and Doris (A8) also formed one of the original workshop teams. All four reported their original group cycle as their first cycle in their respective individual OKGF templates. Their initial group assessment issue (P1) was "What do I do if the majority of my class fails in a test"? Using the assessment principles (TT1) a) "Assessment is fair to all students” (OME, 2008, p. 2-i) and b) “A variety of appropriate assessment formats used to provide additional evidence of learning” (OME, 2008, p. 2-i), they proposed the following solution: "All students will get the opportunity to rewrite the test. Students who passed the previous test will get an opportunity to increase their mark or can choose not to rewrite." The group's discussion of the solution in the EE1 step was

Is this doable? Yes and it gives students the opportunity to improve their mark. However, there are numerous flaws. Students could still do poorly and students who did well on the original test could become angered over students getting another opportunity to write a test. Lastly, a new test will take time to prepare and mark, which could take time away from the class progression in the subject.

As a group, the four pre-service teachers recognized that proposing to whole class the opportunity to rewrite the test might evoke anger in the successful students. Such a rationale is embedded in sociological theory because it considers students as individuals within the group nature of the classroom (Tittle, 1994). However, by expressing the challenges in terms of test preparation and marking, the group of pre-service teachers also referred to the practical issue of feasibility.

Abby's critical thinking (See Appendix 1) regarding finding alternate forms of assessments for the failing students that would not hinder class progress and that would add no extra preparatory burden, is rooted in all three theoretical bases. Allowing the struggling student to catch up is tied to the psychological theory of individual differences; proposing the presentation as an alternative assessment relates to measurement theory, and avoiding hindering her class from moving forward is linked to social theory. It is also considered a feasibility issue because she would need extra time to plan and grade. In her last proposed solution and reasoning, Abby concluded that she had adequately solved her assessment issue. 
She rationalized that, with the revised solution, she had struck a fair balance between two practical bases: classroom assessment "providing sample questions with the class and give one or two on their own" and time management "I will collect these answers and use them for assessment”.

Bella's solution (See Appendix 2) that "the rewrite test will have different types of questions" is partly based on the measurement principle of providing multiple opportunities, but her follow up statement "which will put the entire class behind in the subject" is grounded in social theory. However, as in Abby's reasoning, she rationalized the error in her proposed solution in practical rather than theoretical terms. For instance, she explained that "some students will be left idle", which is a classroom management issue, and "further class time may be required for review”, which is a feasibility issue. In her third cycle, Bella concluded that the problem had been solved by choosing to assign textbook questions as homework that would require parental confirmation of not having assisted their child. This reflects the intersection of measurement theory (varied assessments) and psychological theory (greater student responsibility). Bella's final EE rationale indicated that her proposed solution was feasible and appropriate.

Carrie's assessment issue (See Appendix 3) to provide a fair and reliable final test for most of her students reflects a mixture of measurement theory (reliability) and the social context of fairness. Her reasoning around that issue also reflected the interaction of two theoretical bases. The idea of varying assessment tools (e.g. mini quizzes) and the need to better understand the strengths and weaknesses of the students (formative function), all relate to measurement theory. On the other hand, offering a final test that would "accommodate the various learning styles of all my students” is grounded in psychological theory. As with Bella and Abby, her reasoning also suggested a feasibility concern when she recognized that "this will prove to be difficult for effort, time and preparation”. Although her third assessment issue was also rooted in the interaction of measurement theory "creating multiple final tests' and psychology 'cater toward the student's preferred leaning style”, her proposed solution was refuted principally on the basis of feasibility "too daunting a task". Given that her problem was unresolved at the end of the third cycle, Carrie would have been in a position to further explore her theoretical basis in respecting individual choice within a feasible management context.

Carrie and Doris had similar assessment issues for the second cycle but their reasoning varied. Doris' selection (See Appendix 4) of a principle that specifically referred to the accommodation of special need students clearly referred to psychological theory. However, her reasoning on the application of this principle expanded to her belief in fairness and thus in having all students to choose to do a make up assignment (social theory) in the form of an essay (measurement theory) despite the fact that it would be time consuming (feasibility). As a result, she further explored the idea of using presentations to obtain evidence of "students' understanding of the subject they failed to grasp during the test" (measurement principle). She found her solution to be useful as students would show "extra effort" but also commented on the problem of feasibility and fairness (social theory). 


\subsection{Summary of findings}

Although all four participants' reasoning about their assessment issues were based on the intersection of measurement, psychological and social learning theories, the actual assessment issues identified by the larger group in this anecdotal study differed somewhat from those offered by Brookhart (2004b). In her work, she alluded to issues of feedback, motivation, classroom rules, and formative/summative functions. The larger group in this study identified group work, test failure, accommodation, fairness, multiple and varied assessments, and academic enablers as key areas of concern. The content analysis of the four pre-service teachers' OKGF templates using her framework further stressed measurement issues such as providing multiple opportunities and diversity of assessment tools. Problems principally based on social theory involved avoiding putting the entire class behind and the concept of fairness. Concerns rooted in psychological theory included allowing students to catch up and accommodating different needs/styles. Furthermore, the practical issue of feasibility was reflected in the participants' need of extra instructional time to plan, grade, and review. Classroom management issues, such as leaving class idling, also arose as some point but was not as predominant as Brookhart suggested, perhaps indicating participants' reliance on the assessment principles provided during the workshop, or due to their limited practical experience with assessment in the classroom at the time of the study.

The study's findings, albeit small, contribute meaningfully to the development of a sound theoretical basis for assessment as they further clarify the sources of tension underlying assessment principles and practices. They reveal, to some extent, how some pre-service teachers enter their program with distinct views of and thinking about assessment based on intuition and past experience. Particularly notable in the study, was the greater importance athe pre-service teachers attached to assessment as currency for classroom management, student motivation, and social justice, as opposed to assessment to support learning. The conflicting role of the social dimensions of group work and the individualistic nature of differentiated learning was also apparent. Third, it appears that the topic of academic enablers (i.e. effort, participation) and student dispositions (late or missed assignments) identified as one of the key concerns may continue to plague measurement principles that currently dictate separate assessments and grading of academic enablers and learning achievement (McMillan, 2007; 2008). A fourth critical finding was the predominant practical need for assessment to be feasible first and foremost rather than the theoretical aim of producing valid and reliable assessments, although these technical qualities arose later in the introspective process. Such observations help to understand the frame of mind of the pre-service teachers as they enter the profession and highlight the importance of balancing the practical and theoretical bases of assessment in assessment courses offered in teacher development programs.

Although there has been major efforts in the last twenty years to develop a unified theory of assessment for the educational context that takes into account the culture of learning (Black \& Wiliam, 2006; Gipps, 1994; Pryor \& Crossouard, 2008; Shepard, 2000), higher order learning skills and competencies (Leighton \& Geirl, 2007) and professional judgment within a standards-based environment (Guskey, 2009), such initiatives still fall somewhat short of the exhaustiveness and comprehensive theory needed to cover the complex and 
multidimensional nature of assessment. Despite this shortfall, teacher development programs should still consider applying introspective learning approaches, like the one used in this study, to encourage pre-service teachers to explore the theoretical underpinnings of assessment issues that they self-identify. Not only will this process lead them to achieve some balance between theory and practice, it will also help the academic community to better understand their thinking and actions regarding assessment related issues and to consider these findings in shaping educational assessment theory.

\section{Conclusion, limitations and implications for future research}

The findings in this study provide a glimpse into pre-service teachers' thinking about initial assessment issues and their potential solutions as they enter teacher development programs. The analysis of these concerns using Brookhart's framework (2004b) and of the reasoning about them suggests that the intersection of measurement, psychological, and social theories continues to impact their decision making process regarding assessment. Although these observations need to be further empirically researched, they do point to an emerging list of classroom assessment themes that merit specific attention in teacher development programs. In her study on pre-service teachers' working assessment theories and their resulting concerns after being mentored, Graham (2005) observed that "[T]he issue of developing teachers' skills and knowledge about assessment points to a major problem in education today: if teachers cannot provide evidence of student learning, stakeholders in education will turn to someone or something they think can provide evidence” (p. 619). We agree that phenomena such as standardized large-scale assessments may continue to be valued over classroom assessment if teacher development program do not properly prepare them in that area. Hence, teacher programs should foster deeper understanding and knowledge of theories of assessment, perhaps through professional development approaches such as mentoring and structured group or individual self-reflective approaches.

The effect of the intersection of the three theories on assessment decision making processes should be further investigated within the interaction of standards-based assessment paradigm (Guskey, 2009; Guskey \& Jung, 2006; McMillan, 2008; Sauve Johnson, 2001) and of the socio-constructivist view of assessment to support learning (Klenowki, 2008; Lund, 2008; Shepard, 2000). Concerned about accountability and transparency, standard-based assessment differs from measurement-based assessment in that it a) stresses criterion-referenced and self-referenced approaches to grading; b) advocates greater professional judgment; and c) suggests that only the assessment results that best reflect students' achievement be considered in their final grade (Senk, et al., 1997). The assessment principles associated with the standards-based and socio-constructivist paradigms may result in an even greater significant gap than that found in this study.

It would also be interesting to conduct further research on which internal and external influences affect pre-service teachers' decision making process particularly with respect to choosing principles. McMillan (2003) and Saxe et al (1999) found that experienced teachers are affected by previous knowledge, beliefs, values, expectations, emotions, and identity. They are also pressed by external influences such as curriculum related documents, policies, 
professional development programs, large-scale assessments (institutional impacts), and stakeholders such as colleagues, administration, students, and parents.

The study findings must be interpreted in light of certain limitations related to the particular nature and conditions of the study. For instance, the OKGF template included only three cycles of which one was group initiated. Of particular interest in the pursuit of our study, would be the impact of the group work on the individual thinking about assessment issues and the grading effect on the results. It would also be interesting to provide students with templates with four or five cycles to obtain a better sense of the pre-service teachers' growth in thinking about the underlying theories at play. Moreover, it is difficult at this stage to gage how the field placement may interact with the OKGF with respect to the students' knowledge growth. Furthermore, it is unclear as to how the explicit provision of specific criteria (doable, feasible, useful, and appropriate) affected the pre-service students' reasoning and why feasibility was the most commonly used by the whole group. Finally, deep analyses for this paper were conducted on only four participants' assignments. While it provided a rich and full description of the participants' reasoning, replicating this investigation with the other groups of participants' templates may uncover other noticeable trends that could eventually form the basis for new research propositions in our collective effort to increase our knowledge base in the area of classroom assessment.

\section{Acknowledgement}

The research was financed by the Social Sciences and Humanities Research Council of Canada.

\section{References}

Black, P \& Wiliam, D. (1998). Assessment and Classroom Learning. Assessment in Education, 5(1), p. 7-68.

Black, P., \& Wiliam, D. (2006). Assessment for learning in the classroom. In John Gardner (Ed.), Assessment and Learning, pp.9-25. Thousand Oaks: Sage Publications.

Brookhart, S. M. (1993). Teachers' grading practices: Meaning and values. Journal of Educational Measurement, 30(2), 123-142.

Brookhart, S. M. (1994). Teachers' grading practices: Practice and theory. Applied Measurement in Education, 7(4), 279-301.

Brookhart, S. M. (1999). Teaching about communicating assessment results and grading. Educational Measurement: Issues and Practice, 18(1), 5-13.

Brookhart, S. M. (2004a). Assessment strategies for college teachers. New Directions for Teaching and Learning, 100, 5-14.

Brookhart, S. M. (2004b). Classroom Assessment: Tensions and intersections in theory and practice. Teachers College Record, 106(3), 429-458.

Childs, R. \& Lawson, A. (2003). What do teacher candidates know about large-scale 
assessments? What should they know? Alberta Journal of Educational Research, 49(4), 354.

Chitpin, S. (2006). The use of reflective journal in initial Teacher Training: A Popperian analysis. Reflective Practice, 7(1), 73-86.

Cowie, B., \& Bell, B. (1999). A model of formative assessment in Science education. Assessment in Education: Principles, Policy \& Practice, 6(1), 101-116.

Creswell, J. W. (2009). Research design: Qualitative, Quantitative, and Mixed Methods Approaches (3rd ed.). Thousand Oaks, California: Sage Publications.

Duncan, C. R. \& Noonan, B. (2007). Factors affecting teachers' grading and assessment practices. Alberta Journal of Educational Research, 53(1), 1-21.

Gipps, C.V. (1994). Beyond testing: Towards a theory of educational assessment. Washington, DC: The Falmer Press.

Graham, P. (2005). Classroom-based assessment: Changing knowledge and practice through preservice teacher education. Teaching and Teacher Education, 21, 601-521.

Guskey, T. R. (2009). Synthesis of issues and implications for practice. In Thomas R. Guskey (Ed.), Practical Solutions for Serious Problems in Standards-Based Grading. Thousand Oaks, CA: Corwin Press.

Guskey, T., \& Jung, I. A. (2006). The challenges of standards-based grading. Leadership Compass, 4(2), 1-4.

Harris, L., \& Brown, G. T. L. (2008). New Zealand Teachers' Conceptions of the Purpose of Assessment: Phenomenographic Analyses of Teachers' Thinking. Paper presented at the Australian Association for Research in Education Conference, Brisbane

Harris, L., Irving, S. E., \& Peterson, E. (2008). Secondary Teachers' Conceptions of the Purpose of Assessment and Feedback. Paper presented at the Australian Association for Research in Education Conference, Brisbane

Leighton, J., \& Gierl, M.J. (2007). Defining and evaluating models of cognition used in educational measurement to make inferences about examinees' thinking processes. Educational Measurement: Issues and Practice, 26(2), 3-16.

Lund, A. (2008). Assessment made visible: Individual and collective practices. Mind, Culture, and Activity, 15, 32-51.

Marzano, R.J. (2000). Transforming Classroom Grading. Alexandria: ASCD.

McMillan, J. H. (2001). Secondary teachers' classroom assessment and grading practices. Educational Measurement: Issues and Practices, 20(1), 20-32.

McMillan, J. H. (2003). Understanding and improving teachers' classroom assessment decision making: Implications for theory and practice. Educational Measurement: Issues and Practice, 22(4), 34-43. 
McMillan, J. H. (2007). Classroom Assessment: Principles and Practice for Effective Teaching. $\left(4^{\text {th }}\right.$ ed.) Boston, MA: Pearson Education Inc.

McMillan, J. H. (2008). Assessment Essentials for Standards-based Education. (2 ${ }^{\text {nd }}$ ed.). Thousand Oaks: Corwin Press, SAGE Company.

McMillan, J.H. (2000). Fundamental assessment principles for teachers and school administrators. Practical Assessment, Research \& Evaluation, 7(8). [Online] Available: http://Pareonline.net/getvn.asp?v=7\&n=8 (September 10, 2010).

Newman, L. (2003). Social Research Methods: Qualitative and Quantitative approaches (5th ed). Toronto: Pearson Education. Inc.

Ontario Ministry of Education. (2008). Growing Success. Toronto.

Popper, K. (1972). Objective Knowledge. Oxford, UK: Oxford University Press.

Pryor, J., \& Crossouard, B. (2008). A socio-cultural theorisation of formative assessment. Oxford Review of Education, 34(1), p. 1-20.

Sauve Johnson, J. K. (2001). The Grading of Elementary Student Performance on a Standards-based Report Card. Unpublished Doctoral Dissertation. University of Washington.

Saxe, G. B., Gearhart, M., Franke, M. L., Howard, S., \& Crockett, M. (1999). Teachers’ shifting assessment practices in the context of education reform in mathematics. Teaching and Teacher Education, 15(1), 85-105.

Senk, S. L., Beckman, C. H., \& Thompson, D. R. (1997). Assessment and grading in high school Mathematics classrooms. Journal for Research in Mathematics Education, 28(2), 187-215.

Shepard, L. A. (2000). The role of assessment in a learning culture. Educational Researcher, 29(7), 4-14.

Stiggins, R .J. (1990). Toward a relevant classroom assessment research agenda. The Alberta Journal of Educational Research, XXXVI(1), 92-97.

Stiggins, R. J. (2004). New assessment beliefs for a new school mission. Phi Delta Kappan, 86(1), 22-27.

Stiggins, R. J., Frisbie, D. A., \& Griswold, P. A. (1989). Inside high school grading practices: Building a research agenda. Educational Measurement: Issues and Practices, 1, 5-14.

Tittle, C. K. (1994). Toward an educational psychology of assessment for teaching and learning: Theories, contexts, and validation arguments. Educational Psychologist, 29, 149-162.

Torrance, H \& Prior, J. (2001). Developing formative assessment in the classroom: Using action research to explore and modify theory. British Educational Research Journal, 27(5), 615-631. 


\section{Macrothink

Volante, L., \& Fazio, X. (2007). Exploring teacher candidates' assessment literacy: Implications for teacher education reform and professional development. Canadian Journal of Education, 30(3), 749-770.

Wellington, J., \& Szczerbinski, M. (2007). Research Methods for the Social Sciences. New York and London: Continuum International Publishing Group.

Wiggins, G., and McTighe, J. (nd). Understanding by Design: A Brief Introduction. Center for Technology \& School Change at Teachers College, Columbia University. [Online] Available http://www.davis.k12.ut.us/schools/heritage/files/065C44A161E64F6BA9FC6B64B370357B .pdf (July 6, 2008).

\section{Glossary}

OKGF Objective Knowledge Growth Framework

OME Ontario Ministry of Education 


\section{Appendix}

Appendix 1 Abby

\begin{tabular}{|c|c|c|}
\hline Cycle 1 & Cycle 2 & Cycle 3 \\
\hline $\begin{array}{l}\text { Identification of Assessment } \\
\text { Issue (PI): } \\
\text { What do I do if the majority of } \\
\text { my class fails a test? }\end{array}$ & $\begin{array}{l}\text { Identification of Assessment Issue } \\
\text { (P2): } \\
\text { Other than a re-write test, what other } \\
\text { kind of assessment can I use for those } \\
\text { students who failed the test? }\end{array}$ & $\begin{array}{l}\text { Identification of Assessment Issue } \\
\text { (P3): } \\
\text { What type of assessment can } \\
\text { demonstrate a student's } \\
\text { comprehension of the material } \\
\text { without hindering the progression of } \\
\text { the class? }\end{array}$ \\
\hline $\begin{array}{l}\text { Identification of principle } \\
\text { (TT1) } \\
\text { "Assessment and evaluation } \\
\text { strategies that are fair to all } \\
\text { students” Growing Success \# } 5 \\
\text { All students will get the } \\
\text { opportunity to rewrite the test. } \\
\text { Students who passed the } \\
\text { previous test will get an } \\
\text { opportunity to increase their } \\
\text { mark or can choose not to } \\
\text { rewrite. }\end{array}$ & $\begin{array}{l}\text { Identification of principle (TT2): } \\
\text { UBD design stage } 2 \text { " A variety of } \\
\text { appropriate assessment formats used } \\
\text { to provide additional evidence of } \\
\text { learning”. Instead of a test, students } \\
\text { will be allowed to give a brief } \\
\text { presentation to the class explaining } \\
\text { what they have learned. }\end{array}$ & $\begin{array}{l}\text { Identification of principle (TT3): } \\
\text { UBD stage } 2 \text { "Are students asked to } \\
\text { exhibit their understanding through } \\
\text { authentic performance tasks?". } \\
\text { Instead of a test or presentation, I will } \\
\text { do a few sample questions with the } \\
\text { class and then give them } 1 \text { or } 2 \\
\text { questions to do their own. I will } \\
\text { collect these answers and use them } \\
\text { for assessment. }\end{array}$ \\
\hline $\begin{array}{l}\text { Error Elimination (EE1): } \\
\text { Is this doable? Yes and it gives } \\
\text { students the opportunity to } \\
\text { improve their mark. However, } \\
\text { there are numerous flaws. } \\
\text { Students could still do poorly } \\
\text { and students who did well on } \\
\text { the original test could become } \\
\text { angered over students getting } \\
\text { another opportunity to write a } \\
\text { test. Lastly, a new test will take } \\
\text { time to prepare and mark, } \\
\text { which could take time away } \\
\text { from the class progression in } \\
\text { the subject. }\end{array}$ & $\begin{array}{l}\text { Error Elimination (EE2): } \\
\text { Is this doable? Yes, and it will allow } \\
\text { those students who struggle with test } \\
\text { writing to improve their grade } \\
\text { through a presentation. However, this } \\
\text { will take up a great deal of time for } \\
\text { both students and the teacher. (i.e.: } \\
\text { preparation, grading, presentation } \\
\text { time, etc) It will also hinder the class } \\
\text { from moving forward in the subject } \\
\text { area. }\end{array}$ & $\begin{array}{l}\text { Error Elimination (EE3): } \\
\text { Is this doable? Yes, and it allow me to } \\
\text { get a better feel for what my students } \\
\text { know. It will also help me to identify } \\
\text { those students who are struggling } \\
\text { with the material. This method is also } \\
\text { less time-consuming and will not } \\
\text { hinder the progression of the class. }\end{array}$ \\
\hline
\end{tabular}


Appendix 2. Carrie

\begin{tabular}{|c|c|c|}
\hline $\begin{array}{l}\text { Identification of Assessment } \\
\text { Issue (PI): } \\
\text { What do I do if the majority of } \\
\text { my class fails a test? }\end{array}$ & $\begin{array}{l}\text { Identification of Assessment Issue } \\
\text { (P2): } \\
\text { How do I provide a fair and reliable } \\
\text { final test to most of my students? }\end{array}$ & $\begin{array}{l}\text { Identification of Assessment Issue } \\
\text { (P3): } \\
\text { How can I create a final-test that } \\
\text { accommodates the different learning } \\
\text { styles of the students? }\end{array}$ \\
\hline $\begin{array}{l}\text { Identification of principle } \\
\text { (TT1): } \\
\text { 1) “Assessment and evaluation } \\
\text { strategies that are fair to all } \\
\text { students" Growing Success \# } 5 \\
\text { 2) UBD design stage } 2 \text { " A } \\
\text { variety of appropriate } \\
\text { assessment formats used to } \\
\text { provide additional evidence of } \\
\text { learning”. All students will get } \\
\text { the opportunity to re-do a } \\
\text { revised test. Students who did } \\
\text { well on the first test will have } \\
\text { the opportunity to improve } \\
\text { their mark if they so choose. }\end{array}$ & $\begin{array}{l}\text { Identification of principle (TT2): } \\
\text { "Teachers must use assessment and } \\
\text { evaluation strategies that are varied } \\
\text { in nature, administered over a } \\
\text { period of time, and designed to } \\
\text { provide students with opportunities } \\
\text { to demonstrate the full range of } \\
\text { their learning” Growing Success \# } 6 \\
\text { I can create mini quizzes/ exercises } \\
\text { which vary in format to } \\
\text { accommodate students with } \\
\text { different learning styles (e.g. hands } \\
\text { on activities, visual quizzes, oral } \\
\text { activities) These methods of } \\
\text { assessment will be a precursor for } \\
\text { the final test. }\end{array}$ & $\begin{array}{l}\text { Identification of principle (TT3): } \\
\text { “Address both what students learn and } \\
\text { how well they learn” Growing Success } \\
\text { \# 1. I can create multiple final-tests, } \\
\text { each designed to cater towards a } \\
\text { student's preferred learning style (e.g. } \\
\text { oral, hands-on, visual or written final } \\
\text { tests) }\end{array}$ \\
\hline $\begin{array}{l}\text { Error Elimination (EE1): } \\
\text { Is this doable? Yes, and it gives } \\
\text { students the opportunity to } \\
\text { improve their mark. However, } \\
\text { there are numerous flaws. } \\
\text { Students could still do poorly } \\
\text { on the re-test, while the } \\
\text { students who did well } \\
\text { originally will be angered and } \\
\text { could cause tension within the } \\
\text { class. Lastly, a new test will be } \\
\text { time consuming (ie } \\
\text { preparation, marking, etc) and } \\
\text { will like take away from } \\
\text { students' progression in the } \\
\text { subject. }\end{array}$ & $\begin{array}{l}\text { Error Elimination (EE2): } \\
\text { Is it useful? Yes because it provides } \\
\text { me with a better understanding of } \\
\text { the strengths and weaknesses of my } \\
\text { students before they take the } \\
\text { final-test/ I can then design a final } \\
\text { test that is fair and reflects the } \\
\text { learning abilities of my students as } \\
\text { best as possible. However it will be } \\
\text { challenging to design a final-test } \\
\text { that accommodates the various } \\
\text { learning styles of all my students. } \\
\text { This will prove to be difficult for } \\
\text { effort, time and preparation. Also, it } \\
\text { would not be fair to accommodate } \\
\text { certain learning styles and not } \\
\text { other. }\end{array}$ & $\begin{array}{l}\text { Error Elimination (EE3): } \\
\text { Is this feasible? No given that it would } \\
\text { require ample time to prepare and } \\
\text { evaluate several final-tests, which are } \\
\text { in different formats. It would also be } \\
\text { extremely challenging to design final } \\
\text {-tests in various formats that are } \\
\text { equally fair and represent the same } \\
\text { learning material. On the flipside, it } \\
\text { does present students with the choice of } \\
\text { choosing a final-test assessment that } \\
\text { best represents their learning style. } \\
\text { Still, it would be too daunting a task to } \\
\text { expect teachers to create and evaluate } \\
\text { final-tests fairly in several different } \\
\text { formats. }\end{array}$ \\
\hline
\end{tabular}


Appendix 3 Bella

\begin{tabular}{|c|c|c|}
\hline $\begin{array}{l}\text { Identification of Assessment } \\
\text { Issue (PI): } \\
\text { What can I do if the majority of } \\
\text { my class fails a test? }\end{array}$ & $\begin{array}{l}\text { Identification of Assessment Issue } \\
\text { (P2): } \\
\text { What type of assessment and test } \\
\text { should I use for the rewrite of the } \\
\text { students who failed? }\end{array}$ & $\begin{array}{l}\text { Identification of Assessment } \\
\text { Issue (P3): } \\
\text { What type of assessment can } \\
\text { provide me with evidence of my } \\
\text { student's comprehension of the } \\
\text { material covered by the test that } \\
\text { was failed by the majority of the } \\
\text { class? }\end{array}$ \\
\hline $\begin{array}{l}\text { Identification of principle (TT1): } \\
\text { "Assessment and evaluation } \\
\text { strategies that are fair to all } \\
\text { students" Growing Success \#5. All } \\
\text { students will get the opportunity to } \\
\text { rewrite the test. Students who } \\
\text { passed the previous test will get an } \\
\text { opportunity to increase their mark } \\
\text { or can choose not to rewrite. }\end{array}$ & $\begin{array}{l}\text { Identification of principle (TT2): } \\
\text { UBD stage } 2 \text { "A variety of } \\
\text { appropriate assessment formats used } \\
\text { to provide additional evidence of } \\
\text { learning" Growing Success \# 6. The } \\
\text { rewrite test will have different types } \\
\text { of questions. }\end{array}$ & $\begin{array}{l}\text { Identification of principle } \\
\text { (TT3): } \\
\text { 1) UBD stage } 2 \text { " Students asked } \\
\text { to exhibit their understanding } \\
\text { through authentic performance } \\
\text { tasks" } \\
\text { 2) "Communicate assessment } \\
\text { information with students, teacher } \\
\text { and parents" Growing Success \# } \\
\text { 11. I will assign homework and } \\
\text { question from the textbook and } \\
\text { have the students' parents sign a } \\
\text { form stating that the parents did } \\
\text { not aid their children during their } \\
\text { homework and that they ensure } \\
\text { that the students did nit receive } \\
\text { any other assistance. }\end{array}$ \\
\hline $\begin{array}{l}\text { Error Elimination (EE1): } \\
\text { Is this doable? Yes and it gives } \\
\text { students the opportunity to } \\
\text { improve their mark. However, } \\
\text { there are numerous flaws. Students } \\
\text { could still do poorly and students } \\
\text { who did well on the original test } \\
\text { could become angered over } \\
\text { students getting another } \\
\text { opportunity to write a test. Lastly, } \\
\text { a new test will take time to prepare } \\
\text { and mark, which could take time } \\
\text { away from the class progression in } \\
\text { the subject. }\end{array}$ & $\begin{array}{l}\text { Error Elimination (EE2): } \\
\text { Is this doable? No, if I take the time } \\
\text { to rewrite an entirely new test, } \\
\text { students who are not rewriting will } \\
\text { have nothing to keep them occupied } \\
\text { during the rewrite. However, if I have } \\
\text { the rewrite during lunch or after } \\
\text { school, then no student will be left } \\
\text { idle. If the rewrite goes poorly then } \\
\text { further class time is necessary for } \\
\text { review, which will put the entire class } \\
\text { behind in the subject. }\end{array}$ & $\begin{array}{l}\text { Error Elimination (EE3): } \\
\text { Is this doable? Yes, instead of } \\
\text { taking the time to prepare and } \\
\text { grade a new test I can use } \\
\text { questions already prepared by the } \\
\text { textbook and I can have students } \\
\text { review the material at home. By } \\
\text { informing the parents I can ensure } \\
\text { that they are aware of their child's } \\
\text { difficulties enabling them to } \\
\text { facilitate their... }\end{array}$ \\
\hline
\end{tabular}




\section{Macrothink}

Appendix 4 Doris

\begin{tabular}{|c|c|c|}
\hline $\begin{array}{l}\text { Identification of Assessment } \\
\text { Issue (PI): } \\
\text { What do I do if the majority of my } \\
\text { class fails a test? }\end{array}$ & $\begin{array}{l}\text { Identification of Assessment Issue } \\
\text { (P2): } \\
\text { How can I provide a fair and reliable } \\
\text { assessment to most of my students? }\end{array}$ & $\begin{array}{l}\text { Identification of Assessment } \\
\text { Issue (P3): } \\
\text { What assessment can I use to } \\
\text { provide me with evidence of } \\
\text { students' understanding of the } \\
\text { subject they failed to grasp during } \\
\text { the test? }\end{array}$ \\
\hline $\begin{array}{l}\text { Identification of principle (TT1): } \\
\text { 1) Assessment and evaluation } \\
\text { strategies that are fair to all } \\
\text { students } \\
\text { 2) UBD design stage } 2 \text { " A variety } \\
\text { of appropriate assessment formats } \\
\text { used to provide additional } \\
\text { evidence of learning”. All students } \\
\text { will get the opportunity to re-do a } \\
\text { revised test. Students who did well } \\
\text { on the first test will have the } \\
\text { opportunity to improve their mark } \\
\text { if they so choose. }\end{array}$ & $\begin{array}{l}\text { Identification of principle (TT2): } \\
\text { Teachers must use assessment and } \\
\text { evaluation strategies that } \\
\text { accommodate the needs of students } \\
\text { with special education needs, } \\
\text { consistent with the strategies outlined } \\
\text { in their Individual Education Plan. } \\
\text { All students will get an opportunity } \\
\text { to do a make up assignment if they so } \\
\text { choose. The assignment can be an } \\
\text { essay on the subject tested. }\end{array}$ & $\begin{array}{l}\text { Identification of principle } \\
\text { (TT3): } \\
\text { UBD stage } 2 \text { Are students asked } \\
\text { to exhibit their understanding } \\
\text { through authentic performance } \\
\text { tasks?" \& “assessments used as } \\
\text { feedback for students and } \\
\text { teachers as well as for } \\
\text { evaluators". I can ask students to } \\
\text { make up a presentation if they } \\
\text { want to make-up the marks they } \\
\text { lost they can choose to do it on } \\
\text { the subject in any way they } \\
\text { choose (Bristol board, } \\
\text { powerpoint, speech, etc) }\end{array}$ \\
\hline
\end{tabular}




\section{Macrothink Institute}

\section{Error Elimination (EE1):}

Is this doable? Yes, and it gives students the opportunity to improve their mark. However, there are numerous flaws. Students could still do poorly on the re-test, while the students who did well originally will be angered and could cause tension within the class. Lastly, a new test will be time consuming (ie preparation, marking, etc) and will like take away from students' progression in the subject.

\section{Error Elimination (EE2):}

Is it feasible? Yes, and it gives students the opportunity to move up the marks they lost. However, again it would be very time consuming. I do not believe it would be possible if the teacher has other marking to do. It would be difficult for the teacher to take more time out of their schedule to mark make-up assignment. It would take even more time to construct the assignment in a way to get the same kind of information that the test offered.
Error Elimination (EE3):

Is it useful? Yes, it would show students made an extra effort and they can be questioned after the presentation to expose their understanding. However again it is time consuming. You will have to use up class time forcing you to push your plans to the next day. It does give you the opportunity to evaluate the students' understanding and it gives them a chance to gain back their marks. I feel a teacher (because of the constraints) would not be able to do anything of re-testing, assignments etc. A teacher needs to identify what the problem was and change the way they construct their next test in a way to incorporate more learning strategies. Find the problem and fix it. Otherwise it is unfair to students who did well.

\section{Copyright Disclaimer}

Copyright reserved by the author(s).

This article is an open-access article distributed under the terms and conditions of the Creative Commons Attribution license (http://creativecommons.org/licenses/by/3.0/). 